\title{
Studi Retrospektif: Profil Penggunaan Obat Analgesik pada Pasien Pascatonsilektomi di Departemen SMF THT-KL RSUD Dr. Soetomo Surabaya Tahun 2015-2016
}

\section{A Retrospective Study: Profile of Anagesic Drugs Administration for Post Tonsillectomy Patients in SMF THT-KL Department RSUD Dr. Soetomo Surabaya 2015-2016}

\author{
Tha’atam Mardhiyah ${ }^{\otimes *}$, Maulydia Cholid ${ }^{* *}$, Muhtarum Yusuf*** \\ *Fakultas Kedokteran, Universitas Airlangga, Surabaya, Indonesia \\ **Departemen Anestesiologi dan Reanimasi, Fakultas Kedokteran, Universitas Airlangga, \\ Surabaya, Indonesia \\ *** Departemen Kesehatan Telinga Hidung Tenggorokan - Kepala Leher, Fakultas Kedokteran, \\ Universitas Airlangga, Surabaya, Indonesia
}

${ }^{\square}$ Korespondensi: thaatam.mardhiyah@gmail.com

\begin{abstract}
Background: Pain is the most common complaint occurring on the first day after tonsillectomy and is a significant obstacle in the rehabilitation process of posttonsillectomy patients. Administration of analgesics on the first day after tonsillectomy is proven to relieve pain. Researchers conducted observations on the profile of analgesic drugs administration for patients post tonsillectomy in RSUD Dr. Soetomo Surabaya.

Objective: To observe the profile of analgesic drugs administration for post tonsillectomy patients in SMF THT-KL Department RSUD Dr. Soetomo Surabaya 2015-2016.

Methods: A descriptive retrospective study was done observing the profile of analgesic drugs administration regarded on most analgesic drugs used, multimodal analgesia, early and advanced analgesics, age groups of children and adults and route of administration. The study also included sociodemography (sex and age) of patients and levels of pain after analgesic administration.

Result: Out of 28 samples, the most common analgesic group used was pyrazolone (metamizol, antrain) (51.3\%), and in combination therapy the most used was tramadol with ketorolac (33.3\%). Eight patients (28.6\%) out of 28 patients received advanced analgesics of different types. Metamizole was the most used drugs for pediatric patients (57.7\%), while in adult patients was dominated by ketorolac (50\%).

Conclusion: The administration of metamizole is still a popular option in the treatment of post-tonsillectomy pain, followed by ketorolac for adults patients. There is also a combination of tramadol with ketorolac which is an option in multimodal therapy.
\end{abstract}

Keywords: analgesic; analgesic post-tonsillectomy; pain post-tonsillectomy; postoperative pain management; profile of analgesic administration post-tonsillectomy; tonsillectomy 


\begin{abstract}
ABSTRAK
Latar Belakang: Nyeri merupakan keluhan yang umum terjadi pada hari pertama pascatonsilektomi dan merupakan hambatan yang signifikan dalam proses rehabilitasi. Pemberian analgesik yang dimulai sejak hari pertama pascatonsilektomi dapat meringankan nyeri. Peneliti melakukan pengamatan terhadap profil penggunaan obat analgesik pada pasien pascatonsilektomi di RSUD Dr. Soetomo Surabaya.
\end{abstract}

Tujuan: Mengetahui profil penggunaan obat analgesik dalam penanganan nyeri pada pasien pascatonsilektomi.

Metode: Penelitian ini merupakan retrospektif deskriptif dengan mengamati profil pemberian obat analgesik berdasarkan golongan obat analgesik terbanyak, analgesik tunggal dan kombinasi, analgesik awal dan lanjutan, berdasarkan kelompok umur anak dan dewasa dan cara pemberian. Penelitian juga akan meliputi sosiodemografi (jenis kelamin dan umur) pasien dan tingkatan nyeri setelah pemberian analgesik.

Hasil: Dari 28 sampel, kelompok analgesik yang paling banyak digunakan adalah pyazolon (metamizol, antrain) (51,3\%), sedangkan pada terapi kombinasi didominasi tramadol dengan ketorolak (33,3\%). Sebanyak delapan pasien $(28,6 \%)$ dari total 28 pasien menerima analgesik lanjutan dari jenis lain. Metamizol adalah obat yang paling banyak digunakan untuk pasien anak-anak $(57,7 \%)$, sedangkan pada pasien dewasa didominasi ketorolak (50\%).

Kesimpulan: Pemberian metamizol masih menjadi pilihan dalam penanganan nyeri pascatonsilektomi, diikuti oleh ketorolak yang paling diberikan kepada pasien dewasa. Terdapat juga kombinasi tramadol dengan ketorolak yang menjadi pilihan pada terapi multimodal. Jalur pemberian analgesik dengan rute intravena paling banyak dilakukan pada penanganan nyeri pascatonsilektomi.

Kata Kunci: analgesik; analgesik pascatonsilektomi; manajemen nyeri pascaoperasi; nyeri pascatonsilektomi; profil analgesik pascatonsilektomi; tonsilektomi 


\section{PENDAHULUAN}

Tonsilektomi merupakan suatu prosedur pembedahan untuk mengangkat keseluruhan tonsila palatina dari fossa tonsilaris beserta fascia yang meliputinya dengan cara diseksi atau menggunakan guillotine (snare operation). ${ }^{1}$

Prosedur pembedahan tonsilektomi pada anak-anak maupun dewasa dilaksanakan lebih dari 530.000 di Amerika Serikat setiap tahunnya. ${ }^{2}$ Di Indonesia sendiri belum ada pendataan nasional mengenai jumlah operasi tonsilektomi. Prosedur pembedahan tonsilektomi dilaksanakan sebanyak 207 kasus di Rumah Sakit Dr. Hasan Sadikin Bandung dalam rentang periode Januari 2009 hingga Desember $2011 .^{3}$

Indikasi absolut dari tonsilektomi diantaranya adalah hiperplasia adenotonsillar dengan obstructive sleep apnea (OSA), gagal tumbuh kembang, pertumbuhan abnormal dentofasial, kecurigaan malignansi dan tonsilitis hemoragik. Indikasi relatif yaitu hiperplasia adenotonsillar disertai obstruksi jalan napas, disfagia, gangguan bicara, serta halitosis. Selain itu, faringotonsilitis rekurens atau kronis, abses peritonsillar dan infeksi streptokokus juga merupakan indikasi relatif tonsilektomi. ${ }^{4}$ Kontraindikasi tonsilektomi yaitu rhinitis dan asma kecuali telah ditetapkan diagnosis tonsilitis dengan kecenderungan perdarahan dan epidemi penyakit infeksi. $^{5}$

Nyeri menurut International Association for the Study of Pain (IASP) didefinisikan sebagai pengalaman sensorik dan emosional yang tidak menyenangkan, berkaitan dengan kondisi aktual atau potensial terjadinya kerusakan jaringan. ${ }^{6}$ Nyeri dapat juga didefinisikan sebagai suatu mekanisme protektif sebagai tanda bahwa sedang atau akan terjadi kerusakan jaringan. Sensasi nyeri bersifat subjektif dan dapat juga disertai dengan respons perilaku. ${ }^{7}$

Terdapat berbagai cara dalam pengukuran nyeri yang dapat dilakukan, diantaranya adalah pengukuran menggunakan skala kategorik, visual analogue scale (VAS), numerical rating scale (NRS), pengukuran nyeri multidimensional, dan Wong-Baker faces pain rating scale (WBFS). Penilaian nyeri yang dilakukan di RSUD Dr. Soetomo adalah menggunakan wong-baker faces pain rating scale (WBFS) dengan modifikasi penambahan NRS (Gambar 1).

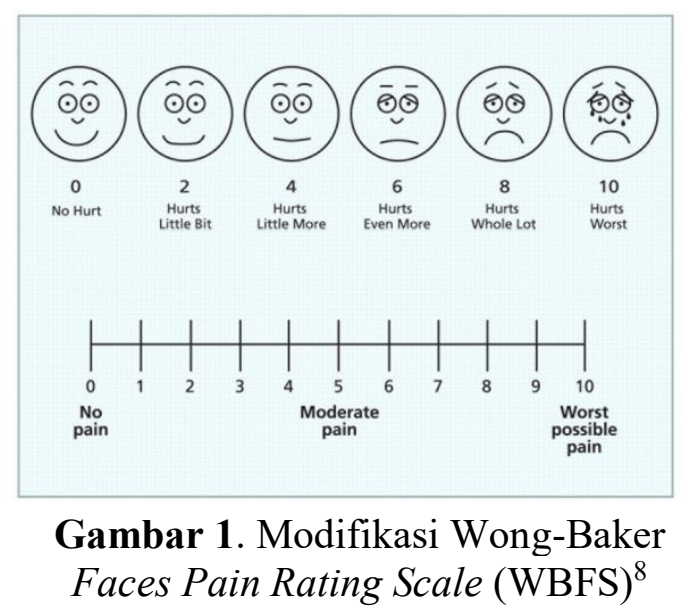

Skala nyeri WBFS merupakan metode penilaian nyeri menggunakan gambar wajah dengan berbagai ekspresi nyeri dan pasien diminta untuk menunjuk gambar yang menggambarkan seberapa besar nyeri yang dirasakan.

Meskipun tonsilektomi merupakan prosedur yang cukup umum dilakukan, terdapat risiko-risiko dan berbagai variasi dalam penatalaksanaan tonsilektomi. $^{2}$ Penyebab utama morbiditas pascatonsilektomi adalah nyeri orofaringeal, yang dapat 
mengakibatkan penurunan asupan, disfagia, dehidrasi, dan penurunan berat badan. ${ }^{9}$

Nyeri merupakan keluhan utama yang terjadi terutama pada hari pertama pascatonsilektomi dan dapat menjadi hambatan yang signifikan dalam proses pemulihan pasien pascatonsilektomi. ${ }^{10}$ Nyeri pascatonsilektomi disebabkan oleh trauma yang terjadi pada saat dilakukan prosedur pembedahan dan hal ini dapat menimbulkan suatu peradangan akut, gangguan menelan. Spasme otot dapat juga menyebabkan nyeri pascatonsilektomi. Hal ini disebabkan karena spasme otot yang terjadi akan menekan pembuluh darah intramuskular dan mengurangi aliran darah. Kontraksi otot dapat juga menimbulkan iskemia otot relatif sehingga mengakibatkan terjadinya kerusakan jaringan dan berdampak pada rangsangan nyeri. ${ }^{11}$

Nyeri pascatonsilektomi meliputi nyeri sedang hingga berat yang berlangsung hingga hari ke tujuh sampai dua minggu dengan penurunan secara gradual. ${ }^{12} \mathrm{Pada}$ penelitian Guntinas-Lichius et al. mengenai variabilitas nyeri pascatonsilektomi, skala VAS maksimal pada pasien yang baru saja menjalani operasi tonsilektomi rata-rata adalah enam atau termasuk ke dalam kategori "nyeri sedang". ${ }^{13}$

Manajemen untuk mengatasi nyeri pascatonsilektomi yang tidak sesuai dapat meningkatkan angka kunjungan ke rumah sakit dan meningkatkan biaya pengobatan. Untuk itu diperlukan perhatian khusus mengenani pemberian analgesik pascatonsilektomi. ${ }^{14}$ Analgesik merupakan senyawa yang digunakan sebagai terapi anti nyeri yang bekerja dengan cara menekan fungsi sistem saraf pusat (SSP) pada jalur perjalanan nyeri secara selektif dan meningkatkan nilai ambang persepsi rasa nyeri. ${ }^{15}$ Analgesik dapat digolongkan menurut struktur kimia dan cara kerjanya yaitu opioid dan golongan non-opioid. Adapun golongan non-opioid terdiri dari golongan salisilat, asam asetat, cyclooxygenase-2 (COX-2) inhibitor, fenamat, asam proprionat, asetaminofen, dan pirazolon. ${ }^{16}$ Pemberian analgesik yang dimulai sejak hari pertama pascatonsilektomi telah diteliti dapat meringankan nyeri. ${ }^{14}$

World Health Organization (WHO) telah mengeluarkan pedoman terbaru untuk mengatasi nyeri yang disebut $\mathrm{New}$ Adaptation of WHO Analgesic Ladder. Dalam pedoman ini disebutkan penanganan nyeri akut atau nyeri pascaoperasi dapat diawali dengan prosedur yang invasif seperti blok syaraf, blok epidural, patient-controlled analgesia (PCA) pump dan dilanjutkan dengan pemberian opioid kuat. Setelah itu pemberiannya dapat dilanjutkan dengan opioid lemah dan diikuti oleh pemberian nonsteroidal antiinflammatory drug (NSAID) atau analgesik non-opioid (Gambar 2).

Salah satu terapi yang direkomendasikan saat ini sebagai penanganan nyeri pascatonsilektomi adalah dengan pemberian analgesik multimodal seperti NSAID dan parasetamol dengan opioid. ${ }^{18}$ Analgesik opioid juga masih menjadi pilihan utama dalam terapi nyeri pascatonsilektomi. Beberapa juga menyarankan untuk memulai dengan pemberian NSAID dan parasetamol pada pasien anak-anak untuk menghindari berbagai efek samping yang mungkin ditimbulkan analgesik opioid. Meskipun begitu, pemilihan obat analgesik untuk penanganan nyeri pascatonsilektomi harus disesuaikan dengan tingkatan nyeri, usia pasien, dan kontraindikasi khusus pasien. ${ }^{19}$ 


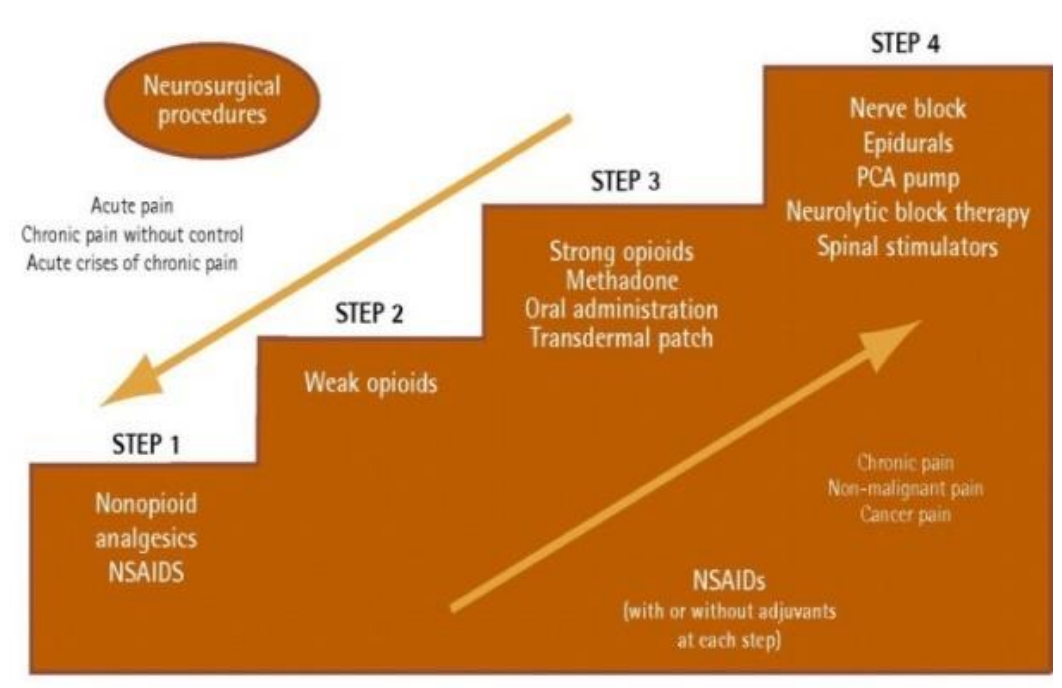

Gambar 2. New Adaptation of WHO Analgesic Ladder ${ }^{17}$

\section{METODE}

Jenis penelitian ini adalah deskriptif retrospektif dengan mengumpulkan data hasil rekam medis kemudian dikelompokkan berdasarkan sosiodemografi pasien, yaitu umur dan jenis kelamin, tingkatan nyeri, jenis obat analgesik dan cara pemberian obat analgesik.

Besar sampel yang diteliti adalah 28 sampel dengan kriteria inklusi yakni semua rekam medis pasien pascatonsilektomi yang berusia lebih dari lima tahun dan menerima obat analgesik di ruang pulih sadar RSUD Dr. Soetomo Surabaya. Pengambilan sampel pada penelitian ini menggunakan teknik total sampling seluruh pasien pascatonsilektomi di Departemen SMF THT-KL RSUD Dr. Soetomo Surabaya tahun 2015-2016.
Penelitian dilakukan di Bagian Pemasaran dan Rekam Medis RSUD Dr. Soetomo Surabaya dengan rentang waktu penelitian yakni bulan Januari 2017 hingga Agustus 2017.

\section{HASIL}

Dari hasil penelitian (Tabel 1) didapatkan data jenis kelamin terbanyak pada pasien tonsilektomi adalah laki-laki (57\%). Kelompok umur dengan pasien terbanyak adalah kelompok 5-14 tahun yaitu 21 pasien (75\%) (Tabel 2).

Jumlah pasien kelompok umur anakanak (1-18 tahun) lebih banyak dibandingkan dengan kelompok umur dewasa (lebih dari 18 tahun), yaitu sebanyak 22 pasien anak-anak $(78,6 \%)$ (Tabel 3). 
Tabel 1. Data karakteristik pasien pascatonsilektomi berdasarkan jenis kelamin

\begin{tabular}{lcc}
\hline \multicolumn{1}{c}{ Jenis Kelamin } & Jumlah Pasien $(\mathrm{n})$ & Persentase $(\%)$ \\
\hline Laki-laki & 16 & 57 \\
Perempuan & 12 & 43 \\
\hline Jumlah & 28 & 100 \\
\hline
\end{tabular}

Tabel 2. Data karakteristik pasien pascatonsilektomi berdasarkan kelompok umur

\begin{tabular}{lcc}
\hline \multicolumn{1}{c}{ Kelompok Umur (Tahun) } & Jumlah Pasien (n) & Persentase (\%) \\
\hline $5-14$ & 21 & 75 \\
$15-24$ & 3 & 10,71 \\
$25-44$ & 3 & 10,71 \\
$45-64$ & 1 & 3,58 \\
$>=65$ & 0 & 0 \\
\hline Jumlah & 28 & 100 \\
\hline
\end{tabular}

Tabel 3. Data karakteristik pasien pascatonsilektomi berdasarkan kelompok usia anakanak dan dewasa

\begin{tabular}{lccc}
\hline \multicolumn{1}{c}{ Kelompok Umur } & Umur & Jumlah Pasien $(\mathrm{n})$ & Persentase (\%) \\
\hline Anak-anak & $1-18$ tahun & 22 & 78,6 \\
Dewasa & $>=19$ & 6 & 21,4 \\
\hline Jumlah & & 28 & 100 \\
\hline
\end{tabular}

Dari hasil penelitian (Tabel 4) didapatkan bahwa pasien terbanyak mengalami "nyeri ringan" $(35,7 \%)$. Didapatkan pula data bahwa 13 pasien $(46,4 \%)$ tidak dinilai tingkatan nyerinya.

Golongan obat analgesik terbanyak yang digunakan adalah turunan pirazolon (metamizol, antrain), yaitu sebanyak 20 pasien $(51,3 \%)$ (Tabel 5). Pada terapi awal, metamizol adalah obat tunggal terbanyak yang diberikan (56\%), sementara itu dalam bentuk kombinasi, tramadol dan ketorolak paling banyak diberikan (33,3\%). Pada terapi lanjutan, obat tunggal terbanyak yang digunakan adalah ketorolak (37,5\%). Tidak ada terapi kombinasi yang diberikan kepada pasien pada terapi lanjutan (Tabel 6).

Sebanyak delapan pasien $(28,6 \%)$ dari total 28 pasien menerima analgesik lanjutan dengan jenis yang berbeda. Obat analgesik awal yang diganti dengan analgesik lanjutan adalah ketorolak $(37,5 \%)$, metamizol (37,5\%), dan kombinasi tramadol dengan ketorolak (25\%). Pada penelitian ini tidak dapat diketahui alasan pasti penggantian obat tersebut (Tabel 7).

Pada pasien anak, obat analgesik terbanyak yang digunakan adalah metamizol (57,7\%), sementara kombinasi metamizol dan parasetamol menjadi satu-satunya obat kombinasi yang diberikan kepada pasien anak $(3,8 \%)$ (Tabel 8).

Untuk terapi awal, cara pemberian analgesik dengan jalur intravena digunakan pada semua pasien. Adapun pada terapi lanjutan, pemberian analgesik melalui jalur intravena adalah yang terbanyak (87,5\%) (Tabel 9). 
Tabel 4. Penilaian WBFS (Wong-Baker Faces Pain Rating Scale) pasien pasca anestesi

\begin{tabular}{lccc}
\hline \multicolumn{1}{c}{ Skala WBFS } & Interpretasi & Jumlah Pasien $(\mathrm{n})$ & Persen tase $(\%)$ \\
\hline 0 & Tidak nyeri & 5 & 17,9 \\
$1-3$ & Nyeri ringan & 10 & 35,7 \\
$4-6$ & Nyeri sedang & 0 & 0 \\
$7-10$ & Nyeri berat & 0 & 0 \\
Tidak ada data & & 13 & 46,4 \\
\hline Jumlah & & 28 & 100 \\
\hline
\end{tabular}

Tabel 5. Data pengobatan pasien pascatonsilektomi berdasarkan golongan obat

\begin{tabular}{lcc}
\multicolumn{1}{c}{ Golongan Analgesik } & Jumlah Pasien (n) & Persentase (\%) \\
\hline Opioid (tramadol, morfin) & 2 & 5,1 \\
$\begin{array}{l}\text { Turunan Salisilat (aspirin, } \\
\text { diflunisal) }\end{array}$ & 0 & 0 \\
Turunan Asam Asetat (ketorolak) & 12 & 30,8 \\
$\begin{array}{l}\text { COX-2 Inhibitor (Colecoxib, } \\
\text { nimesulid) }\end{array}$ & 0 & 0 \\
$\begin{array}{l}\text { Turunan Fenamat (asam } \\
\text { mefenamat) }\end{array}$ & 1 & 2,6 \\
$\begin{array}{l}\text { Turunan Asam Proprionat } \\
\text { (ibuprofen) }\end{array}$ & 0 & 0 \\
$\begin{array}{l}\text { Asetaminofen (parasetamol) } \\
\text { Turunan Pirazolon (metamizol, }\end{array}$ & 4 & 10,2 \\
antrain) & 20 & 51,3 \\
\hline Jumlah & 39 & 100 \\
\hline
\end{tabular}

Tabel 6. Data pengobatan pasien pascatonsilektomi berdasarkan penggunaan analgesik tunggal dan kombinasi

\begin{tabular}{lcccccccc}
\hline \multirow{2}{*}{ Nama Obat } & \multicolumn{4}{c}{ Analgesik awal } & \multicolumn{3}{c}{ Analgesik lanjutan } \\
& \multicolumn{2}{c}{ Tunggal } & Kombinasi & \multicolumn{2}{c}{ Tunggal } & Kombinasi \\
& $\mathrm{n}$ & $\%$ & $\mathrm{n}$ & $\%$ & $\mathrm{n}$ & $\%$ & $\mathrm{n}$ & $\%$ \\
\hline Tramadol & 0 & 0 & 2 & 33,3 & 0 & 0 & 0 & 0 \\
Ketorolak & 7 & 28 & 2 & 33,3 & 3 & 37,5 & 0 & 0 \\
Asam Mefenamat & 0 & 0 & 0 & 0 & 1 & 12,5 & 0 & 0 \\
Parasetamol & 2 & 8 & 1 & 16,7 & 1 & 12,5 & 0 & 0 \\
Metamizol & 14 & 56 & 1 & 16,7 & 1 & 12,5 & 0 & 0 \\
Antrain & 2 & 8 & 0 & 0 & 2 & 5 & 0 & 0 \\
\hline Jumlah & 25 & 100 & 6 & 100 & 8 & 100 & 0 & 0 \\
\hline
\end{tabular}


Tabel 7. Data pengobatan pasien pascatonsilektomi berdasarkan jenis analgesik awal yang diganti dengan analgesik lanjutan

\begin{tabular}{|c|c|c|c|c|c|}
\hline \multicolumn{3}{|c|}{ Terapi Awal } & \multicolumn{3}{|c|}{ Terapi Lanjutan } \\
\hline $\begin{array}{l}\text { Analgesik } \\
\text { Awal }\end{array}$ & $\begin{array}{c}\text { Jumlah Pasien } \\
\text { (n) }\end{array}$ & $\begin{array}{c}\text { Persentase } \\
(\%)\end{array}$ & $\begin{array}{c}\text { Analgesik } \\
\text { Lanjutan }\end{array}$ & $\begin{array}{c}\text { Jumlah Pasien } \\
\text { (n) }\end{array}$ & $\begin{array}{c}\text { Persentase } \\
(\%)\end{array}$ \\
\hline \multirow{4}{*}{ Ketorolak } & \multirow{4}{*}{7} & \multirow{4}{*}{28} & $\begin{array}{l}\text { Asam } \\
\text { Mefenamat }\end{array}$ & 1 & 14,3 \\
\hline & & & Metamizol & 1 & 14,3 \\
\hline & & & Parasetamol & 1 & 14,3 \\
\hline & & & Jumlah & 3 & 42,9 \\
\hline \multirow[t]{2}{*}{$\begin{array}{c}\text { Tramadol + } \\
\text { Ketorolak }\end{array}$} & 2 & 25 & Ketorolak & 2 & 100 \\
\hline & & & Jumlah & 2 & 100 \\
\hline \multirow{4}{*}{ Metamizol } & \multirow{4}{*}{14} & \multirow{4}{*}{56} & Antrain & 2 & 14,3 \\
\hline & & & Ketorolak & 1 & 7,1 \\
\hline & & & Jumlah & 3 & 21,4 \\
\hline & & & Total & 8 & 28,6 \\
\hline
\end{tabular}

Tabel 8. Data jenis obat analgesik yang digunakan pasien pascatonsilektomi berdasarkan kelompok usia anak dan dewasa

\begin{tabular}{lrrrr}
\hline \multirow{2}{*}{ Nama Obat } & \multicolumn{4}{c}{ Yang Mendapatkan Terapi Analgesik } \\
\cline { 2 - 5 } & $\mathrm{n}$ & $\%$ & $\mathrm{n}$ & Dewasa \\
\cline { 2 - 5 } & 0 & 0 & 0 & $\%$ \\
\hline Tramadol & 4 & 15,4 & 4 & 0 \\
Ketorolak & 1 & 3,8 & 0 & 50 \\
Asam Mefenamat & 1 & 3,8 & 2 & 0 \\
Parasetamol & 15 & 57,8 & 0 & 25 \\
Metamizol & 4 & 15,4 & 0 & 0 \\
Antrain & 0 & 0 & 2 & 0 \\
Tramadol + Ketorolak & 1 & 3,8 & 0 & 25 \\
Metamizol + Parasetamol & 26 & 100 & 8 & 0 \\
\hline Jumlah & & & & 100 \\
\hline
\end{tabular}

Tabel 9. Data cara pemberian obat analgesik pada pasien pascatonsilektomi

\begin{tabular}{lcc}
\hline Cara Pemberian & Jumlah Pasien (n) & Persentase (\%) \\
\hline Terapi Awal & & 100 \\
\hline Intravena & 28 & 0 \\
Peroral & 0 & 87,5 \\
\hline Terapi Lanjutan & & 12,5 \\
\hline Intravena & 7 & \\
Peroral & 1 & \\
\hline
\end{tabular}




\section{PEMBAHASAN}

Dari hasil penelitian didapatkan data jenis kelamin terbanyak pada pasien tonsilektomi adalah laki-laki (57\%). Hasil ini mendukung penelitian yang dilakukan Sembiring di Manado, dimana dari 20 sampel didapatkan jenis kelamin laki-laki sebanyak $55 \%{ }^{20}$ Begitu juga pada penelitian Ugras dan Ahmed di Turki, dari 120 pasien tonsillitis kronis, didapatkan 66 (55\%) laki-laki. ${ }^{21}$ Hasil berbeda didapatkan pada penelitian Fakh et al., sebanyak $56 \%$ pasien dari 50 pasien tonsilitis kronis di Padang adalah perempuan. $^{22}$ Pada penelitian yang dilakukan Sapitri di RSUD Raden Mattaher Jambi didapatkan pula dari 30 pasien mayoritas jenis kelamin adalah perempuan $17(56,7 \%))^{23}$ Terdapat perbedaan dari beberapa hasil penelitian terkait jenis kelamin dominan yang menjalani tonsilektomi. Hal ini dapat disebabkan oleh jumlah populasi sampel yang diteliti.

Berdasarkan hasil penelitian, kelompok umur dengan pasien terbanyak adalah kelompok 5-14 tahun yaitu 21 pasien (75\%). Jumlah pasien kelompok umur anak-anak (1-18 tahun) lebih banyak dibandingkan dengan kelompok umur dewasa (lebih dari 18 tahun), yaitu sebanyak 22 pasien anak-anak $(78,6 \%)$.

Hasil penelitian ini sesuai dengan penelitian Sapitri tentang karakteristik penderita tonsilitis kronis yang diindikasikan tonsilektomi di Jambi; dari 30 sampel didapatkan distribusi terbanyak usia 5-14 tahun $(50 \%){ }^{23}$ Penelitian yang dilakukan Fakh et al. di Padang juga menyebutkan hal yang serupa; dari 50 pasien, kelompok terbanyak penderita tonsilitis kronis adalah kelompok umur 10-14 tahun $(50 \%) .{ }^{22}$ Farokah dalam penelitiannya di Semarang juga mendapatkan distribusi terbanyak yaitu pada kelompok usia delapan tahun $(69,8 \%)$ dari total 38 sampel. ${ }^{10}$

Rentang umur terbanyak pasien yang menjalani tonsilektomi adalah 5-14 tahun. Hal ini dikarenakan pada usia 310 tahun terjadi aktivitas imunologi terbesar tonsil dan gambaran respon imun selular pada tonsilitis kronis menunjukkan terjadinya peningkatan deposit antigen pada jaringan tonsil. Selain itu, anak menjelang usia pertama sekolah (lima tahun ke atas) sangat rentan terhadap virus dan bakteri dari lingkungan sekitar, mengingat pada usia tersebut belum terbentuk sistem kekebalan yang sempurna. ${ }^{24}$

Dari hasil penelitian didapatkan bahwa pasien-pasien terbanyak mengalami "nyeri ringan" (35,7\%). Didapatkan pula data bahwa 13 pasien $(46,4 \%)$ tidak dinilai tingkatan nyerinya.

Pada penelitian Guntinas-Lichius et al. mengenai variabilitas nyeri pascatonsilektomi, skala VAS maksimal pada pasien yang baru saja menjalani operasi tonsilektomi rata-rata adalah 6 atau termasuk ke dalam kategori "nyeri sedang". ${ }^{13}$

Terdapat berbagai faktor yang menyebabkan tingkatan nyeri pasien pada penelitian ini tergolong rendah yaitu: (1) Komunikasi, Informasi, dan Edukasi (KIE) yang dilakukan oleh anestesiologis kepada pasien sudah baik sehingga persepsi nyeri rendah, (2) Nyeri adalah sensasi subjektif pasien yang berbeda tiap individunya, dan dapat diketahui dari penelitian ini bahwa ambang nyeri pasien cukup tinggi, (3) Obat analgesik yang diberikan sudah tepat obat, tepat indikasi, tepat dosis, dan tepat cara pemberian sehingga nyeri dapat teratasi dengan baik. Nyeri yang 
berkurang pada pasien pascatonsilektomi setelah menerima analgesik terjadi melalui proses yang berbeda tergantung dari obat analgesik yang diberikan.

Golongan obat analgesik terbanyak yang digunakan adalah turunan pirazolon (metamizol, antrain), yaitu sebanyak 20 pasien (51,3\%). Hasil yang sama didapatkan pada penelitian Chandra et al. di Manado yang menyebutkan bahwa metamizol adalah analgesik paling banyak yang diberikan kepada pasien anak-anak $(54,55 \%)$ dari total 52 sampel. ${ }^{25}$

Berdasarkan Formularium Nasional 2015, metamizol injeksi $500 \mathrm{mg} / \mathrm{mL}$ diterima sebagai tambahan pilihan terapi untuk nyeri pascaoperasi. Metamizol termasuk ke dalam daftar obat yang ditanggung oleh pemerintah, hal ini dapat menjadi salah satu alasan mengapa metamizol paling banyak digunakan pada pasien pascatonsilektomi di RSUD Dr. Soetomo Surabaya.Dalam penelitian Kocum et al. disimpulkan bahwa parasetamol dan metamizol intravena adalah analgesik yang efisien untuk digunakan pada periode awal pascatonsilektomi pada 120 sampel anak-anak. ${ }^{26}$

Walaupun di berbagai negara penggunaan metamizol seringkali dihindari karena dapat menimbulkan efek samping agranulositosis, beberapa penelitian menunjukkan variasi dari risiko agranulositosis yang disebabkan penggunaan metamizol. Meskipun begitu, pasien harus tetap dimonitor terutama pada penggunaan metamizol jangka panjang. Efek samping yang mungkin timbul ini harus juga dibandingkan dengan efek samping obat analgesik lainnya yang juga dapat berpotensi mengancam jiwa. ${ }^{27}$
Pada terapi awal, metamizol adalah obat tunggal terbanyak yang diberikan (56\%), sementara itu dalam bentuk kombinasi, tramadol dan ketorolak paling banyak diberikan (33,3\%). Pada terapi lanjutan, obat tunggal terbanyak yang digunakan adalah ketorolak (37,5\%). Tidak ada terapi kombinasi yang diberikan kepada pasien pada terapi lanjutan.

Pada penelitian yang dilakukan Meilissa di Balikpapan didapatkan juga hasil yang serupa, yakni obat kombinasi terbanyak yang digunakan untuk mengatasi nyeri pascaoperasi adalah kombinasi tramadol dan ketorolak $(8,47 \%){ }^{28}$

Pencegahan dari nyeri menggunakan analgesik multimodal telah terbukti efektif untuk mengatasi hampir semua nyeri pascaoperasi. Teknik menggunakan analgesik multimodal berdasarkan empat kelas analgesik yaitu anestesi lokal, opioid, NSAID dan asetaminofen. $^{29}$ Terapi menggunakan analgesik multimodal dinilai cukup efektif dengan didasari pada prinsip farmakologi obat yaitu prinsip efek aditif dan sinergis antara berbagai golongan analgesik. Analgesik multimodal memungkinkan untuk dilakukannya pemberian dalam dosis yang lebih rendah sehingga dapat menghindari efek samping dan mempersingkat durasi perawatan sehingga menurunkan biaya pengobatan. $^{19}$

Penelitian Enriquez juga menyebutkan kombinasi tramadol dan ketorolak aman dan efektif untuk penanganan nyeri pascaoperasi, onkologis dan nyeri terbakar pada anak-anak. ${ }^{30}$

Sebanyak delapan pasien $(28,6 \%)$ dari total 28 pasien menerima analgesik lanjutan dengan jenis yang berbeda. Obat analgesik awal yang diganti dengan analgesik lanjutan adalah ketorolak 
$(37,5 \%)$, metamizol $(37,5 \%)$, dan kombinasi tramadol dengan ketorolak $(25 \%)$. Pada penelitian ini tidak dapat diketahui alasan pasti penggantian obat tersebut.

Penelitian yang dilakukan Rawal et al. menyebutkan bahwa persentase pasien yang membutuhkan analgesik tambahan adalah $23 \%$ dengan tramadol sebagai terapi awal, 31\% dengan metamizol, dan $42 \%$ dengan Parasetamol. ${ }^{31}$

Terdapat beberapa alasan penggantian obat analgesik diantaranya adalah: (1) munculnya keluhan seperti nyeri lambung dan mual muntah, (2) munculnya efek samping yang tidak diinginkan pada pasien seperti reaksi alergi obat, (3) mencegah pemberian analgesik jangka panjang, (4) persiapan kepulangan pasien, dan alasan lainnya.

Pada pasien anak, obat analgesik terbanyak yang digunakan adalah metamizol (57,7\%), sementara kombinasi metamizol dan parasetamol menjadi satu-satunya obat kombinasi yang diberikan kepada pasien anak $(3,8 \%)$.

Parasetamol dan metamizol intravena adalah analgesik yang efisien untuk digunakan di periode awal pascatonsilektomi pada anak-anak. ${ }^{26}$ Metamizol adalah obat analgesik yang dapat dijadikan alternaif bagi pasien dengan kontraindikasi NSAID atau dengan riwayat gangguan pencernaan atas, lambung dan ginjal. Insiden kejadian agranulositosis pada anak karena penggunaan metamizol masih menjadi kontroversi, akan tetapi risiko tersebut dapat dikurangi dengan penggunaan metamizol untuk jangka pendek. ${ }^{32}$ Fieler et al. yang melakukan penelitian mengenai terapi metamizol untuk mengatasi nyeri pascaoperasi pada 1177 anak-anak; menyimpulkan bahwa pemberian metamizol intravena berguna untuk mencegah atau mengatasi nyeri pascaoperasi dan aman digunakan pada lebih dari 1000 anak-anak. Probabilitas terjadinya gangguan hemodinamik, anafilaksis, dan reaksi respiratoris kurang dari $0,3 \%{ }^{33}$

Analgesik tramadol pada penelitian ini tidak pernah diberikan kepada pasien anak-anak. Tramadol tidak direkomendasikan sebagai analgesik pereda nyeri pascabedah pada anakanak. ${ }^{34}$ Efek samping lebih signifikan ditemukan pada penggunaan tramadol pada anak-anak pascaoperasi tonsilektomi. ${ }^{35}$

Pemberian obat analgesik tunggal pascatonsilektomi pada pasien dewasa didominasi oleh ketorolak yang diberikan kepada empat pasien dewasa (50\%). Hasil yang sama didapatkan pada penelitian Chandra et al. yang menyebutkan obat analgesik yang paling banyak digunakan adalah obat ketorolak, sebanyak 31 pasien $(59,61 \%), 2$ pasien di antaranya anak-anak dan 29 pasien lainnya dewasa. ${ }^{25}$ Ketorolak tidak dianjurkan untuk digunakan pada anakanak karena belum adanya penelitian yang adekuat mengenai hal ini dan penggunaan ketorolak pada pasien dewasa dapat ditoleransi dengan baik. ${ }^{36}$ Riwijanti dalam penelitiannya mengenai efek analgesik pemakaian ketoprofen dan ketorolak intravena pascatonsilektomi menyimpulkan bahwa pengamatan tentang nyeri, tekanan darah, frekuensi denyut jantung, frekuensi napas dan efek samping. Ketorolak $30 \mathrm{mg}$ intravena memiliki efektifitas analgesik lebih baik, dibanding dengan ketoprofen $100 \mathrm{mg}$ intravena. ${ }^{37}$ 
Untuk terapi awal, cara pemberian analgesik dengan jalur intravena digunakan pada semua pasien. Adapun pada terapi lanjutan, pemberian analgesik melalui jalur intravena adalah yang terbanyak $(87,5 \%)$.

Parasetamol dan metamizol memiliki keefektifan dan tolerabilitas yang lebih tinggi apabila diberikan secara intravena pada pasien pascatonsilektomi. ${ }^{38}$ Penelitian lain menyebutkan, parasetamol intravena dapat bekerja dengan onset yang lebih cepat dan efektif dibandingkan parasetamol oral dengan dosis yang sama. ${ }^{39}$ Pemberian obat analgesik dengan rute intravena memiliki keuntungan diantaranya adalah bioavailabilitasnya penuh, menghindari first pass dan dapat menjadi pilihan bagi pasien tidak sadar atau kesulitan untuk menelan. ${ }^{35}$

\section{KESIMPULAN}

Penilaian nyeri terbanyak pasien pascatonsilektomi setelah menerima analgesik adalah "nyeri ringan" $(35,7 \%)$ dengan skala modifikasi WBFS 1-4. Golongan obat analgesik terbanyak yang digunakan adalah golongan pirazolon (metamizol, antrain), yaitu sebanyak 20 pasien $(51,3 \%)$. Metamizol adalah obat tunggal terbanyak yang diberikan pada terapi awal dengan jumlah 14 pasien (56\%). Sedangkan untuk terapi kombinasi paling banyak digunakan kombinasi tramadol dengan ketorolak $(33,3 \%)$. Pada terapi lanjutan, obat tunggal terbanyak yang digunakan adalah Ketorolak yang diberikan kepada tiga pasien $(37,5 \%)$.

\section{DAFTAR PUSTAKA}

1. Moore K, Dalley A, Agur A. Clinically oriented anatomy. $4^{\text {th }} \mathrm{ed}$. Canada: Wolters Kluwer
Health/Lippincott Williams \& Wilkins; 2010

2. Randel A. Practice Guidelines: AAO-HNS Guidelines for Tonsillectomy in Children dan Adolescents. American Family Physician. 2011; 84(5): 556-573

3. Atiyah D, Permana A, Hartanto R. Indications of Tonsillectomy and Adenoidectomy in Dr. Hasan Sadikin General Hospital Bandung. Althea Medical Journal. 2015; 2(1): 128

4. Darrow D, Siemens C, Indications for Tonsillectomy and Adenoidectomy. The Laryngoscope. 2009; 112(S100): 610

5. Gray R, Hawthorne M, Groves J. Synopsis of otolaryngology. Oxford: Butterworth-Heinemann; 1992

6. Chandra S. Panduan Tatalaksana Nyeri Perioperatif. Jakarta: Perhimpunan Dokter Spesialis Anestesiologi dan Reanimasi Indonesia; 2009

7. Sherwood L. Fisiologi Manusia dari Sel Ke Sistem. Jakarta: Buku Kedokteran EGC; 2015

8. Rasor J, Harris G. Opioid Use for Moderate to Severe Pain. The Journal of the American Osteopathic Association. 2005; 105(6): 3

9. Baugh R, Archer S, Mitchell R, Rosenfeld R, Amin R, Burns J, et al. Clinical Practice Guideline: Tonsillectomy in Children. Otolaryngology -- Head dan Neck Surgery. 2010; 144(1): S1-S30

10. Farokah F. Efektivitas Infiltrasi Lidokain Pada Peritonsil Untuk Mengurangi Nyeri Pascatonsilektomi. [Disertasi]. Semarang: Diponegoro University; 2012

11. Ohlms L. Injection of Local Anesthetic in Tonsillectomy. Arch 
Otolaryngol Head Neck Surgery. 2001; 127(10): 1276

12. Wiggins S. Commentary: Pain following pediatric tonsillectomy and adenoidectomy: What do we know about home pain management? Pediatric Pain Letter. 2008; 10(1): 1

13. Guntinas-Lichius O, Geisler K, Komann M, Schlattman P, Meissner W. Inter-Hospital Variability of Postoperative Pain after Tonsillectomy: Prospective Registry-Based Multicentre Cohort Study. Plos One. 2016; 11(4):154155

14. Fortier M, MacLaren J, Martin S, Perret-Karimi D, Kain Z. Pediatric Pain After Ambulatory Surgery: Where's the Medication? PEDIATRICS. 2009; 124(4):588595.

15. Siswandono. Kimia Medisinal, $2^{\text {nd }}$ ed, Surabaya: Airlangga University Press; 2008

16. Bhandari G, Shahi K, Parmar N, Asad M, Joshi H, Bhakuni R. Evaluation of analgesic effect of two different doses of fentanyl in combination with bupivacaine for surgical site infiltration in cases of modified radical mastoidectomy: A double blind randomized study'. Anesthesia: Essays dan Researches. 2013; 7(2): 243

17. Vargas-Schaffer G. Is the WHO Analgesic Ladder Still Valid? Canada Family Physician. 2010; 56(6): 514-517

18. Walker S, Pain after surgery in children. Current Opinion in Anaesthesiology. 2015; 28(5): 570576

19. Buvanendran A, Kroin JS. Multimodal Analgesia for Controlling Postoperative Pain.
Wolters Kluwer Health. 2009; 22, hal 588-593

20. Sembiring RO, John P, Olivia W. Identifikasi bakteri dan uji kepekaan terhadap antibiotik pada penderita tonsilitis di poliklinik THT-KL BLU RSU. Prof. Dr. R. D. Kandou Manado periode November 2012Januari 2013. Skripsi. Manado: Fakultas Kedokteran Universitas Sam Ratulangi; 2013

21. Ugras S, Ahmed K. Chronic tonsillitis can be diagnosed with histopahologic findings. European Journal of General Medicine. 2008; 5(2): 95-103

22. Fakh IM, Novialdi, Elmatris. Karakteristik Pasien Tonsilitis Kronis pada Anak di Bagian THTKL RSUP Dr. M. Djamil Padang Tahun 2013. Jurnal Kesehatan Andalas. 2016; 5(2): 439

23. Sapitri V. RSUD Raden Mattaher Jambi. Jambi: Fakultas Kedokteran dan Ilmu Kesehatan Universitas Jambi; 2013

24. Soepardi EA. Buku ajar ilmu kesehatan telinga hidung tenggorok kepala \& leher. Edisi Ke-6. Jakarta: Balai Penerbit FKUI; 2007

25. Chandra C, Tjitrosantoso $\mathrm{H}$, Lolo WA. Studi Penggunaan Obat Analgesik Pada Pasien Cedera Kepala (Concussion) di RSUP Prof. Dr. R. D Kandou Manado Periode Januari-Desember 2014. Pharmacon. 2016; 5(2): 194-204

26. Kocum AI, Sener M, Caliskan E, Bozdogan N, Micozkadioglu D, Yilmaz I, et al. Intravenous paracetamol and dipyrone for postoperative analgesia after daycase tonsillectomy in children: a prospective, randomized, double blind, placebo-controlled study. Brazilian Journal of Otorhinolaryngology. 2013; 79(1): 89-94 
27. Grundmann U, Wornle C, Biedler A, Kreuer S, Wrobel M, Wilhelm W. The Efficacy of the Non-Opioid Analgesics Parecoxib, Paracetamol and Metamizol for Postoperative Pain Relief After Lumbar Microdiscectomy. Anesthesia \& Analgesia. 2006; 103(1): 217-222

28. Meilissa, G. Pola Penggunaan Analgesik pada Pasien Closed dan Opened Fraktur yang Menjalani Bedah Ortopedi dan Rawat Inap di Rumah Sakit Pertamina Balikpapan Periode Januari 2006-Januari 2007. [Tesis] Surabaya: Univesity of Surabaya; 2007

29. Lonnqvist PA, Morton NS. Postoperative Analgesia in Infants and Children. British Journal of Anesthesia. 2005: 95(1): 59-68

30. Enriquez ARV. Analgesic Efficacy and Security of Ketorolac/Tramadol Combination In Children. Revista Mexicana de Pediatria. 2011; 78(2): 61-65

31. Rawal N, Renee A, Anders A, Torbjorn O, Jan H. Postoperative analgesia at Home After Ambulatory Hand Surgery: A Controlled Comparison of Tramadol, Metamizol, and Paracetamol. Anesthesia \& Analgesia. 2001; 92(2):347-351

32. Konijnen-Peters J, Van der Heijden C, Ekhart C, Bos J, Bruhn J, Kramers C. Metamizole (Dipyrone) as an Alternative Agent in Postoperative Analgesia in Patients with Contraindications for Nonsteroidal Anti-Inflammatory Drugs. Pain Practice. 2017; 17(3): 402-408

33. Fieler M, Eich C, Becke K, Badelt G, Leimkuhler K, Messroghli L. et al. Metamizole for Postoperative Pain Therapy in 1177 Chlidren: A Prospective, Multicentre,
Observational, Postauthorisation Safety Study. European Journal of Anaesthesiology. 2015; 32(12): 839-43

34. Badan Pengawas Obat dan Makanan. Analgesik opioid. 2017

35. Friedrichsdorf S, Postier A, Foster L, Lander T, Tibesar R, Lu Y. et al. Tramadol versus codeine/acetaminophen after pediatric tonsillectomy: A prospective, double-blinded, randomized controlled trial. Journal of Opioid Management. 2015; 11(4): 283-294

36. Lynn AM, Bradford H, Kantor ED. Postoperative Ketorolac Tromethamine Use in Infants Aged 6-18 months: The Effect on Morphine Usage, Safety Assesement, and Stereo-spesific Pharmacokinetics. National Library of Medicine National Institutes of Health, 2007; 104(5):1040-51

37. Riwijanti ME. Evaluasi Efek Analgesi Pemakaian Ketoprofen dan Ketorolak Intravena Pascatonsilektomi. [Disertasi]. Semarang: Universitas Diponegoro; 2001

38. Sener M, Kocum A, Caliskan E, Yilmaz I, Caylakli F, Aribogan A. Administration of Paracetamol Versus Dipyrone By Intravenous Patient-Controlled Analgesia for Postoperative Pain Relief in Children After Tonsillectomy. Brazilian Journal of Anesthesiology, 2015; 65(6): 476-82

39. Moller PL, Sindet-Pedersen S, Petersen CT, Juhl GI, Dillenschneider A, Skoglund LA. Onset of Acetaminophen Analgesia: Comparion of Oral and Intravenous Routes After Third Molar Surgery. British Journal of Anaesthesia, 2005; 94(5): 64 